\title{
Profile of the canine population with atopic dermatitis at the dermatology service of the Veterinary Hospital from Federal University of Minas Gerais
}

\author{
Perfil da população canina com dermatite atópica no serviço de dermatologia do Hospital \\ Veterinário da Universidade Federal de Minas Gerais \\ Perfil de la población canina con dermatitis atópica en el servicio de dermatología del Hospital \\ Veterinario de la Universidad Federal de Minas Gerais
}

Received: 08/20/2021 | Reviewed: 08/27/2021 | Accept: 09/02/2021 | Published: 09/04/2021

\author{
Jéssica Ragazzi Calesso \\ ORCID: https://orcid.org/0000-0001-7623-7301 \\ Federal University of Minas Gerais, Brazil \\ E-mail: jessicacalesso@gmail.com \\ Vanessa Stuart Marques \\ ORCID: https://orcid.org/0000-0003-3890-0728 \\ Federal University of Minas Gerais, Brazil \\ E-mail: vanessastuart.vet@gmail.com \\ Adriane Pimenta da Costa-Val Bicalho \\ ORCID: https://orcid.org/0000-0001-8995-9805 \\ Federal University of Minas Gerais, Brazil \\ E-mail: adriane@ufmg.br
}

\begin{abstract}
Canine atopic dermatitis (AD) is an IgE-mediated type I hypersensitivity reaction to sensitization to environmental allergens. Pathogenesis is quite complex, involving genetic and environmental factors, food allergens, skin barrier defects and immune dysfunction. Data on its prevalence and epidemiological aspects in Europe and North America are easily found in the literature. However, when searching for specific national locations, studies are still scarce. Thus, the objective of this study was to determine the prevalence and characteristics of canine $\mathrm{AD}$ at the dermatology service of the Veterinary Hospital from Federal University of Minas Gerais (UFMG). For this purpose, 761 medical records of dogs attended at the service from January 2015 to December 2020 were analyzed. The results revealed that of all dermatological diagnoses in the species, 28,12\% (214/761) of the cases were of dogs with AD. 34,51\% (291/761) of the dermatological cases were from allergic etiology, and of these, AD corresponded to 73,56\% (214/291), representing the most prevalent allergic disease in dogs at the Veterinary Hospital from UFMG. Females were more affected than males, as well as dogs of defined breeds in comparison to mixed breed dogs, with shih tzu being the most prevalent pure breed, followed by mixed breed dogs. Because it is a highly pruritic disease that affects the quality of life of dogs and their owners, this study contributes to a better understanding and diagnostic approach to the disease in the local canine population.
\end{abstract}

Keywords: Allergy; Atopy; Dogs; Dermatitis; Prevalence.

\section{Resumo}

A dermatite atópica (DA) canina é uma reação de hipersensibilidade tipo I, mediada por IgE frente à sensibilização aos alérgenos ambientais. Sua patogênese é bastante complexa, envolvendo fatores genéticos, ambientais, alimentares, defeitos de barreira cutânea e disfunção imunológica. Os dados sobre sua prevalência e aspectos epidemiológicos em países europeus e norte-americanos são encontrados facilmente na literatura. Entretanto, quando se busca por localidades nacionais específicas, os trabalhos ainda são escassos. Desta forma, objetivou-se determinar a prevalência e as características da DA canina no serviço de dermatologia do Hospital Veterinário da Universidade Federal de Minas Gerais (UFMG). Para tanto, foram analisados 761 prontuários de cães atendidos no serviço no período de janeiro de 2015 a dezembro de 2020. Os resultados revelaram que de todos os diagnósticos dermatológicos na espécie, 28,12\% (214/761) dos casos foram de cães com DA. 34,51\% (291/761) da casuística dermatológica eram de etiologia alérgica, e destes, a DA correspondeu a 73,56\% (214/291), representando a alergopatia mais prevalente da espécie no Hospital Veterinário da UFMG. As fêmeas foram mais acometidas do que os machos, assim como cães de raças definidas em relação aos sem raça definida, sendo shih tzu a raça pura mais prevalente, seguida dos cães sem raça definida. Por se tratar de uma doença altamente pruriginosa, que afeta a qualidade de vida dos cães e de seus tutores, tal estudo contribui para melhor compreensão e abordagem diagnóstica da doença na população canina local.

Palavras-chave: Alergia; Atopia; Cães; Dermatite; Prevalência. 


\begin{abstract}
Resumen
La dermatitis atópica canina (DA) es una reacción de hipersensibilidad de tipo I mediada por IgE a la sensibilización a alérgenos ambientales. Su patogenia es bastante compleja, involucrando defectos genéticos, ambientales, alimentarios, de la barrera cutánea y disfunción inmunológica. Los datos sobre su prevalencia y aspectos epidemiológicos en países europeos y norteamericanos se encuentran fácilmente en la literatura. Sin embargo, cuando se buscan ubicaciones nacionales específicas, los trabajos siguen siendo escasos. Así, el propósito de este estudio fue determinar la prevalencia y características de la DA canina en el servicio de dermatología del Hospital Veterinario de la Universidad Federal de Minas Gerais (UFMG). Para eso, se analizaron 761 historias clínicas de perros atendidos en el servicio entre enero de 2015 y diciembre de 2020. Los resultados revelaron que del total de diagnósticos dermatológicos en la especie, 28,12\% (214/761) de los casos fueron de perros com AD. En 34,51\% (291/761) de los casos dermatológicos la etiología fue alérgica, y de estos, la DA correspondío al 73,56\% (214/291), representando la enfermedad alérgica de la especie más prevalente en el Hospital Veterinario de la UFMG. Las hembras se vieron más afectadas que los machos, así como los perros de razas definidas en relación con las razas mixtas, siendo el shih tzu la raza pura más prevalente, seguida de los perros de razas mixtas. Por ser una enfermedad altamente pruriginosa que afecta la calidad de vida de los perros y sus guardianes, este estudio contribuye a una mejor comprensión y enfoque diagnóstico de la enfermedad en la población canina local.
\end{abstract}

Palabras clave: Alergia; Atopia; Perros; Dermatitis; Prevalencia.

\title{
1. Introduction
}

Canine $\mathrm{AD}$ is one of the most frequent chronic dermatopathy in dogs, affecting 20 to $30 \%$ of the canine population (Marsella \& De Benedetto, 2017). It is defined as a genetically predisposed, pruritic, and inflammatory skin disease with clinical signs associated with IgE production against environmental allergens (Olivry et al., 2001; Halliwell, 2006).

Its etiology is multifactorial and not fully elucidated yet. However, it is known that genetic and environmental factors affect both the immune response and the skin barrier function, which can be a primary and secondary factor (Marsella, Sousa, Gonzales \& Fadok, 2012). Pruritus is the most characteristic clinical sign, especially in the acute phase of the disease, and it may not be lesional. Clinical presentation is erythema and papules, followed by excoriations and other self-induced lesions. As the disease progresses, tissue remodeling lesions, in response to chronic inflammation, appear, such as lichenification, hyperpigmentation, and hyperkeratosis (Larsson \& Lucas, 2020).

Diagnosis of canine AD is clinical and based on excluding similar dermatoses, such as other allergic, parasitic, and infectious dermatitis (DeBoer \& Hillier, 2001; Wilhem, Kovalik \& Favrot, 2011; Saridomichelakis \& Olivry, 2016), following the algorithm proposed by Hillier (2002). In addition, Favrot's criteria support the interpretation of clinical findings related to AD and in clinical studies (Favrot, Steffan, Seewald \& Picco, 2010). How it is know that genes with altered expression included those relevant to skin barrier formation and immune function in canine $\mathrm{AD}$, as it is in humans, gene expression in the skin of dogs with AD using quantitative real time PCR (qPCR) may be considered suitable target for future genetic and protein function studies (Wood et al., 2009).

Treatment is multifaceted and mainly focused on four factors: time (acute or chronic lesions), presence of pruritus, inflammation, and secondary infections (Santoro, 2019). Therapeutic approaches have been described by the International Committee on Allergic Diseases of Animals (Olivry et al., 2015). Because canine AD corresponds to a large part of the cases in small animals, the study of this dermatopathy becomes increasingly essential. Although the literature is vast, little information is available on its occurrence according to different national geographic regions. Furthermore, the few epidemiological studies that exist are primarily international (Hill et al., 2006).

Given the increased prevalence of this allergopathy and the divergences in the characteristics of the patients according to intrinsic and extrinsic factors, including geographical aspects, it is necessary to recognize the local canine population with AD, for a better diagnostic and therapeutic approach, which should always be individualized. Therefore, the objective of this study was to determine the prevalence and characterize the canine population with AD attended at the dermatology service of the Veterinary Hospital from UFMG, in Belo Horizonte, Minas Gerais, Brazil, from 2015 to 2020, through a retrospective study. 


\section{Methodology}

A retrospective study with medical records of patients attended at the dermatology service of the Veterinary Hospital from UFMG was carried out, analyzing the following characteristics of the dogs: sex, breed, age, clinical signs, pruritus, occurrence of secondary bacterial and fungal infections, frequency of otitis and concomitant allergies. Comorbidities, dermatological or not, that patients had during follow-up at the dermatology service were also included. Data analysis was descriptive.

To select medical records of dogs with $\mathrm{AD}$, a report was generated through the Veterinary Hospital system, with all records of dermatological appointments realized between January 2015 and December 2020. From this report, dogs that during consultations and follow-up visits had a final diagnosis of canine AD were selected. Dogs that were clinically suspected but had no definitive clinical diagnosis were excluded from the atopic group of the study.

The diagnosis of canine $\mathrm{AD}$ was established by the history, clinical signs and exclusion of other pruritic and inflammatory skin diseases through routine complementary examinations, in addition to having completed the allergic trial with the treatment of secondary infections, elimination of ectoparasites and a restrictive hypoallergenic diet, with commercial hydrolyzed protein or homemade with an unprecedented source of protein, for at least eight weeks.

\section{Results and Discussion}

The period studied ranged from January 2015 to December 2020 and a total of 761 medical records of canine patients with a diagnosed dermatopathy were computed at the dermatology service of the Veterinary Hospital from UFMG. Of these, 214 dogs were clinically diagnosed with canine $\mathrm{AD}$, corresponding to a prevalence of $28,12 \%$ of all dermatological appointments of the species in the period corresponding to five years. Among the most prevalent dermatopathies in the service, the following stand out: 1) allergopathies, with $34,51 \%$ of the cases; 2) infectious dermatitis, with $25,86 \%$, including bacterial and fungal causes; and 3) parasitic dermatitis, with 10,79\% of the cases. Of all allergopathies, canine AD corresponded 73,53\% of the cases, being the most prevalent allergy.

The study of Santos and Santos (2016) characterized the profile of canine AD in Salvador, Bahia, and allergies also corresponded to the majority of dermatopathies in dogs. However, the authors found $\mathrm{AD}$ as the second most frequent allergic disease, with flea allergy dermatitis (FAD) as the most prevalent allergy in the region. This finding corroborates to the found for Cardoso et al. (2011), in northern Paraná, where FAD was the most prevalent allergopathy. However, the study of Souza et al. (2009), carried out in Santa Maria, Rio Grande do Sul, diverges from these findings, since AD was the most prevalent hypersensitivity, corroborating what was observed in this present study, despite the important geographic difference.

Branquinho and Castro (2016), in Distrito Federal, also found AD as the most prevalent allergopathy, corresponding to $80 \%$ of cases, followed by FAD (14\%) and food allergy (6\%). In the study of Gasparetto et al. (2013), allergies ranked second among all dermatopathies in the state of Mato Grosso, with parasitic dermatitis being the most prevalent of the cases. Although less frequent than in the studies mentioned above, canine $\mathrm{AD}$ was also the most diagnosed allergic dermatitis among all allergopathies.

The prevalence of $\mathrm{AD}$ in our study $(28,12 \%)$ was lower than what was found by Amarante, Ramadinha and Pereira (2015), who detected AD in 36,1\% of the dogs attended at the dermatology service of the Universidade Federal Rural do Rio de Janeiro. The higher percentage of cases is probably due to the fact that the number of medical records was significantly higher, with 1.462 dogs studied in the equivalent of the same period (five years).

For sex, females were affected in $58 \%$ of cases, while males, $42 \%$, data that corroborates with other national epidemiological studies (Amarante et al., 2016; Ribeiro et al., 2020; Couceiro et al., 2021). Although it is described in the 
literature that there is no sexual predisposition (Miller, Griffin \& Campbell, 2013), it can be concluded from these studies that females have a higher diagnosis of AD than males.

Breed is an important aspect, represented in Table 1, since it has already been determined that genetic inheritance is a risk factor for the development of $\mathrm{AD}$ and the breed prevalence varies geographically worldwile. It was observed that dogs of specific breed have a greater predisposition than dogs of mixed breed (Amarante et al., 2015; Alves et al., 2018; Ribeiro et al., 2020), as found in this present study, with $88,78 \%$ of the dogs having defined breed and $11,22 \%$ of them having mixed breed. However, Couceiro et al. (2021) found that canine AD was predominant in dogs mixed breed, with 47,9\% of the cases.

The most predisposed breeds to canine AD worldwide, involving data from Germany, Australia and the United States, according to a multicenter study realized by Jaeger et al. (2010), were bichón frisé, boxer, bull terrier, cavalier king charles spaniel, french bulldog and german shepherd. Other breeds such as english bulldog, lhasa apso, labrador retriever, pug, schnauzer, cocker spaniel, west highland white terrier, yorkshire terrier, fox terrier (Miller et al., 2013), as well as jack russell terrier and Golden retriever (Wilhem et al., 2011), are also described as predisposed in foreign literature and several are compatible with those identified in this study.

In several Brazilian studies, the most prevalent pure breed was poodle (Santos \& Santos, 2016; Alves et al., 2018; Ribeiro et al., 2020), differing from the present study, taking fifth place among pure breeds. A significant number of mixed breed atopic dogs was found, in agreement with other authors (Amarante et al., 2015; Santos \& Santos, 2016; Alves et al., 2018; Couceiro et al., 2021). The predominant breeds in this study corroborate those found by Branquinho \& Castro (2016) in Distrito Federal, who had shih tzu and lhasa apso as the breeds most diagnosed with canine AD. The breed prevalence described here is also similar to the most commonly observed in São Paulo: shih tzu, lhasa apso, poodle, french bulldog, english bulldog and pug (Larsson \& Lucas, 2020).

Table 1 - Relative frequency by breed of the canine population with atopic dermatitis at the dermatology service of the Veterinary Hospital from UFMG between 2015-2020:

\begin{tabular}{cc}
\hline Breeds & Relative frequency \\
\hline Shih Tzu & $23,83 \%$ \\
\hline Mixed breed & $11,21 \%$ \\
\hline Lhasa Apso & $9,81 \%$ \\
\hline French Bulldog & $8,41 \%$ \\
\hline Yorkshire Terrier & $6,54 \%$ \\
\hline Poodle & $6,07 \%$ \\
\hline Others & $34,13 \%$ \\
\hline Total & $\mathbf{1 0 0 \%}$ \\
\hline
\end{tabular}

Source: Personal archive.

In the present study was observed that $63,55 \%$ of dogs were up to seven years old at the time of diagnosis, corroborating the most common age of $\mathrm{AD}$ manifestation in the International literature (Miller et al., 2013) and with other national epidemiological studies (Branquinho \& Castro, 2016; Santos \& Santos, 2016; Ribeiro et al., 2020). Amarante et al. (2015) found that $7,95 \%$ of atopic dogs were less than one year old at diagnosis and 21,97\% were less than three years old. This last data agrees with the frequency of dogs diagnosed up to three years of age in this study $(20,56 \%)$ and in the study from Ribeiro et al. (2020), who observed even a higher prevalence $(38,8 \%)$.

The low frequency of dogs diagnosed with less than one year of age can be explained by the probability that the puppies have not had enough exposure to the allergens for sensitization to occur and, therefore, to develop clinical signs. Another 
hypothesis is that most owners search the specialty with the recurrence and chronicity of clinical signs, delaying the moment of definitive diagnosis in these patients. The ages of patients at diagnosis are represented in Table 2.

Table 2 - Frequency by age of the canine population with atopic dermatitis at the dermatology service of the Veterinary Hospital from UFMG between 2015-2020.

\begin{tabular}{cc}
\hline Age in complete years & Relative frequency \\
\hline < 1 year of age & $1,4 \%$ \\
\hline 1 years of age & $2,8 \%$ \\
\hline 2 years of age & $4,67 \%$ \\
\hline 3 years of age & $11,68 \%$ \\
\hline 4 years of age & $11,21 \%$ \\
\hline 5 years of age & $10,75 \%$ \\
\hline 6 years of age & $12,15 \%$ \\
\hline 7 years of age & $8,88 \%$ \\
\hline 8 years of age & $8,88 \%$ \\
\hline 9 years of age & $7,48 \%$ \\
\hline$>10-16$ years of age & $20,09 \%$ \\
\hline Total & $\mathbf{1 0 0 \%}$
\end{tabular}

Source: Personal archive.

Although it does not exist as a pathognomonic clinical sign, pruritus is the most important sign in dogs with $\mathrm{AD}$, and it should be present, because it's absence excludes the diagnosis of this disease (Favrot et al., 2010). Pruritus was the main clinical sign reported by the owners in 78,50\% of the cases, a lower finding compared to the presence of pruritus in study from Ribeiro et al. (2020), with $94,6 \%$ and Alves et al. (2018), with $81,8 \mathrm{I} \%$. In $63,10 \%$ of the cases the pruritus was alesional at the time of diagnosis. In $36,90 \%$, it was already accompanied by primary skin lesions such as erythema and papules. About the location of pruritus and skin lesions, in 59,90\% the interdigital regions were the most affected, with reports of intense interdigital licking and on palmoplantar surfaces; next, the face, with $31,98 \%$ of the dogs presenting itching and facial erythema (periocular and perilabial), accompanied by hypotrichosis and alopecia; and perineum, with $8,10 \%$ of affected dogs.

It is known that the interdigital areas and palmoplantar surfaces are among the most frequently affected in dogs with AD (Favrot et al., 2010; Wilhem et al., 2011; Larsson \& Lucas, 2020). The foot pruritus in this study corroborates with Jaeger et al. (2010), who found $62 \%$ of this region involvement in the dogs included in the study. The low frequency of perineal pruritus $(8,10 \%)$ may be due to the fact that it is more frequent in dogs with food allergies than in dogs with AD (Loeffler, SoaresMagalhães, Bond \& Lloyd, 2006).

For the approach of pruritus, was used the pruritus visual analog scale (pVAS) with an interval of zero to ten centimeters, proposed by Hill, Lau and Rybníček (2007) and Rybníček, Lau-Gillard, Harvey and Hill (2009). Most dogs with AD had severe and very severe pruritus, as shown in Table 3, with the following scores as empirical classification: 1). Absence of pruritus: 01.9; 2). Mild pruritus: $2-4 ; 3$ ). Moderate pruritus: $>4-6$; 4). Severe pruritus: $>6-8$; and 5). Very severe pruritus: $>8-10$. 
Table 3 - Classification of the pruritus degree in the canine population with atopic dermatitis at the dermatology service of the Veterinary Hospital from UFMG between 2015-2020:

\begin{tabular}{cc}
\hline Classification of pruritus & Relative frequency \\
\hline Absent pruritus & $0 \%$ \\
\hline Mild pruritus & $0,6 \%$ \\
\hline Moderate pruritus & $16,67 \%$ \\
\hline Severe pruritus & $44,05 \% \%$ \\
\hline Very severe pruritus & $38,69 \% \%$ \\
\hline Total & $\mathbf{1 0 0 \%}$
\end{tabular}

Source: Personal archive.

Secondary bacterial and fungal skin infections are quite frequent in canine patients with $\mathrm{AD}$ and, in addition to contributing to the worsening of itching and discomfort to the patient, they also act as perpetuators of the allergic inflammatory cascade and skin barrier dysfunction. It is known that $\mathrm{AD}$ is closely related to the development of otitis externa and pruritus in the pinna, and otitis is already considered part of the signs presented by these dogs (Meason-Smith, Olivry, Lawhon \& Hoffmann, 2020). Otitis externa may be present in more than $50 \%$ of the cases (Larsson \& Lucas, 2020). In the study conducted by Ribeiro et al. (2020) otitis was the most frequent secondary sign in dogs with AD, affecting $73 \%$ of them, followed by pyoderma with $30,4 \%$ of cases. Our study found that they were also the two most identified secondary affections in patients, with $42,14 \%$ of patients presenting with otitis externa and $45 \%$ pyoderma. The prevalence of Malassezia overgrowth detected by Ribeiro et al. (2020) was much lower $(1,21 \%)$ than what we found $(7,85 \%)$. The occurrence of superficial pyoderma observed here corroborates with the literature, which shows that 40 to $60 \%$ of atopic dogs have secondary bacterial skin infection (Larsson $\&$ Lucas, 2020).

It is suspected that the prevalence of canine AD in the population attended at the dermatology service of the Veterinary Hospital from UFMG is even higher than that detected $(28,12 \%)$, since, among all the diagnoses of dermatopathies, $20,99 \%$ were from superficial pyoderma and $7,71 \%$ from otitis externa, in other words, it is very likely that these dogs had these conditions as clinical signs of $\mathrm{AD}$, but at that time they did not have the definitive diagnosis to be included as atopic dogs.

Regarding the comorbidities (Table 4) found in atopic dogs, food hypersensitivity (31\%) was the most prevalent in this study, followed by FAD, which also affected a large number of patients, with $25 \%$ of cases. Neoplasms had an important position, having cases of mammary tumors (17\%) and canine mast cell tumors (9\%) diagnosed, probably due to advanced age, breed predisposition and chronic skin inflammation. 
Table 4 - Relative frequency of comorbidities diagnosed in the canine population with atopic dermatitis at the dermatology service of the Veterinary Hospital of UFMG between 2015-2020.

\begin{tabular}{cc}
\hline Comorbidities & Relative frequency \\
\hline Food allergy & $31 \%$ \\
\hline Flea allergy dermatitis & $25 \%$ \\
\hline Mammary tumors & $17 \%$ \\
\hline Mast cell tumors & $9 \%$ \\
\hline Leishmaniasis & $4 \%$ \\
\hline Hyperadrenocorticism & $4 \%$ \\
\hline Hypothyroidism & $2 \%$ \\
\hline Diabetes mellitus & $2 \%$ \\
\hline Chronic facial cutaneous lupus erythematosus & $2 \%$ \\
\hline Lipoma & $2 \%$ \\
\hline Alopecia post-grooming & $2 \%$ \\
\hline Total & $\mathbf{1 0 0 \%}$
\end{tabular}

Source: Personal archive.

It is currently known that food allergens are the cause of $\mathrm{AD}$ flares in dogs with symptoms indistinguishable from those caused by environmental allergens (Olivry, DeBoer \& Prélaud, 2007). The response to the elimination diet trial with new or original protein (homemade or hydrolyzed) can be total, if it is the only cause of the clinical signs, or partial, in cases where the food allergen participates in the pathogenesis of AD (Andrade, 2018). Sensu stricto atopic dermatitis is defined when the condition is responsive only to environmental allergens, and sensu lato atopic dermatitis, when food and environmental allergens are recognized as causing clinical signs (Olivry et al., 2007). It is also important to note that atopic like dermatitis was also recognized and defined as a pruritic and inflammatory dermatopathy with clinical features identical to those seen in dogs with $\mathrm{AD}$, but without an IgE response to environmental allergens (Halliwell, 2006).

It was observed in our study that $31 \%$ of dogs with AD had partial improvement with the hypoallergenic diet, whether homemade with novel protein or commercial with hydrolyzed protein, representing the prevalence of dogs with AD induced by environmental and food allergens in the studied population. Griffin and DeBoer (2001) reported that up to $30 \%$ of dogs with AD had food hypersensitivity simultaneously. However, Zur, Ihrke, White and Kass (2002) reported that only 7\% of dogs with AD were also affected by food hypersensitivity. These data are difficult to compare with each other because they are studies of different designs, variable sizes of the studied groups, geographic location and period in which the studies were carried out.

On the other hand, FAD was concomitantly observed in $25 \%$ of dogs with $\mathrm{AD}$, a finding superior to the found by Ribeiro et al. (2020), which detected 14,8\%. An important and often overlooked fact is that approximately $75 \%$ of dogs with AD may have concomitant FAD and food hypersensitivity (Barbosa, 2015). Our study observed that 56\% of dogs with AD had another diagnosed allergopathy besides canine AD.

Canine mast cell tumor is the most common malignant skin neoplasm in the species and was observed in 9\% (4) of atopic dogs. The retrospective study by Santos (2017) aimed to assess the possible association between chronic skin inflammation and this neoplasm. He found that $55 \%$ of dogs diagnosed with mast cell tumors had a history of chronic skin inflammation, with $25 \%$ of patients having a previous diagnosis of chronic otitis externa, $17,5 \%$ of food allergy and $15 \%$ of AD. He also found that dogs diagnosed with mast cell tumors and a history of chronic cutaneous inflammation had a lower mean of age than those who did not have this history. Furthermore, histologically, these patients had a higher degree of mast cell tumor (Santos, 2017). 


\section{Conclusion}

From the above results, it is concluded that canine AD was the most diagnosed allergopathy in the period studied at the Veterinary Hospital from UFMG. The characteristics of the canine population with AD are in accordance with the literature, affecting mainly dogs of specific breeds, as shih tzu, females, young adults and adults up to seven years of age, who present severe to very severe pruritus as the main clinical sign, especially in interdigital regions, with frequently secondary pyoderma and otitis externa. Furthermore, it was possible to detect that a large number of dogs with AD also had food hypersensitivity and FAD, concomitant allergies that aggravate the clinical signs of the disease, which can trigger atopic flares and influence the therapeutic approach. So, the epidemiological and clinical aspects here studied, are important to diagnostic and classification of the dogs with AD.

\section{References}

Alves, B. H., Viana, J. A., Leira, M. F., Alves e Rodrigues, N. P., Pristo, A. L. P., Maia, L. S., Silva, S. M. V., Marinho, K. A. O., Pereira, M. B., \& Bertoldo, J. B. (2018). Dermatite atópica canina: Estudo de caso. PUBVET, 12(8), 133-139.

Amarante, C. F., Ramadinha, R. R., \& Pereira, M. J. S. (2015). Atopic dermatitis: a restropective study of associated factors in a dermopathic canine population. Revista Brasileira de Medicina Veterinária, 37(1), 13-17.

Andrade, L. S. B. (2018). Aspectos clínicos e epidemiológicos e avaliação da disbiose cutânea em cães com dermatite atópica. Tese (Doutorado), Escola de Veterinária, Universidade Federal de Minas Gerais, Belo Horizonte, Minas Gerais, Brasil.

Barbosa, L. C. (2015). Análise imunohistoquímica da proteína interleucina-31 e filagrina e sua relação com o grau de prurido e restauração da barreira cutânea, antes e após uso de solução repositora de lipídios na epiderme de cães com dermatite atópica. Dissertação (Mestrado), Faculdade de Medicina Veterinária e Zootecnia, Universidade Estadual Paulista, Campus Botucatu, São Paulo, Brasil.

Branquinho, R., \& Castro, T. B. (2016). Levantamento das alergopatias caninas atendidas no Distrito Federal, Brasil, no período de 2013 a 2015. Revista de Educação Continuada em Medicina Veterinária e Zootecnia do CRMV-SP, 13(3), 45-45.

Cardoso, M. J. L., Machado, L. H. A., Melussi, M., Zamarian T. P., Carnielli, C. M., \& Ferreira Júnior, J. C. M. (2011). Dermatopatias em cães: revisão de 257 casos. Archives of Veterinary Science, 16, 66-74.

Couceiro, G. A., Ribeiro, S. M. M., Monteiro, M. M., Meneses, A. M. C., Sousa, S. K. S. A., \& Coutinho, L. N. (2021). Prevalence of canine atopic dermatitis at the Veterinary Hospital of the "Universidade Federal Rural da Amazônia" in Belém/Pará, Brazil. Pesquisa Veterinária Brasileira, 41 , e06778.

DeBoer, D. J. \& Hillier, A. (2001). The ACVD task force on canine atopic dermatitis (XV): Fundamental concepts in clinical diagnosis. Veterinary Immunology and Immunopathology, 81(3-4), 271-276.

Favrot, C., Steffan, J., Seewald, W., \& Picco, F. (2010). A prospective study on the clinical features of chronic canine atopic dermatitis and its diagnosis. Veterinary Dermatology, 21(1), 23-30.

Gasparetto, N. D., Trevisan, N. Y. P.A., Almeida, N. B., Neves, R. C. S. M., Almeida, A. B. P. F., Dutra, V., Colodel, E. M., \& Sousa, V. R. F. (2013). Prevalência das doenças de pele não neoplásicas em cães no município de Cuiabá, Mato Grosso. Pesquisa Veterinária Brasileira, 33(3), 359-362.

Griffin, C. E. \& DeBoer, D. J. (2001). The ACVD task force on canine atopic dermatitis (XIV): clinical manifestations of canine atopic dermatitis. Veterinary Immunology and Immunopathology, 81, 255-269.

Halliwell, R. (2006). Revised nomenclature for veterinary allergy. Veterinary Immunology and Immunopathology, 114(3-4), 207-208.

Hill, P. B., Lau, P., \& Rybníček, J. (2007). Development of an owner-assessed scale to measure the severity of pruritus in dogs. Veterinary Dermatology, 18(5), 301-308.

Hill, P. B., Lo, A., Eden, C. A. N., Huntley, S., Morey, V., Ramsey, S., Richardson, C., Smith, D. J., Sutton, C., Taylor, M. D., Thorpe, E., Tidmarsh, R., \& Williams, V. (2006). Survey of the prevalence, diagnosis and treatment of dermatological conditions in small animals in general practice. Veterinary Record Open, 158(16), 533-539.

Hillier, Definitively diagnosing atopic dermatitis in dogs. (2002). Veterinary Medicine, 97(3, 198-208.

Jaeger, K., Linek, M., Power, H. T., Bettenay, S. V., Zabel, S., Rosychuk, R. A. W., \& Mueller, R. S. (2010). Breed and site predispositions of dogs with atopic dermatitis: a comparison of five locations in three continentes. Veterinary Dermatology, 21, 119-123.

Larsson, C. E. \& Lucas, R (2020). Tratado de medicina externa: dermatologia veterinária (2a ed.), Interbook.

Loeffler, A., Soares-Magalhães, R., Bond, R., \& Lloyd, D. H. (2006). A retrospective analysis of case series using home-prepared and chicken hydrolysate diets in the diagnosis of adverse food reactions in 181 pruritic dogs. Veterinary Dermatology, 17, 273-279.

Marsella, R. \& De Benedetto, A (2017). Atopic Dermatitis in Animals and People: An Update and Comparative Review. Veterinary Sciences, 4(37), 1-19. 
Marsella, R., Sousa, C. A., Gonzales, A. J., \& Fadok, V. A. (2012). Current understanding of the pathophysiologic mechanisms of canine atopic dermatitis. Journal of the American Veterinary Medical Association, 241(2), 194-207.

Meason-Smith, C., Olivry, T., Lawhon, S. D., \& Hoffmann, A. R. (2020). Malassezia species dysbiosis in natural and allergen-induced atopic dermatitis in dogs. Medical Mycology Journal, 58(6), 756-765.

Miller, W. H., Griffin, C. E., \& Campbell, K. L. (2013). Muller \& Kirk’s: Small Animal Dermatology (7th ed). Missouri: Elsevier.

Olivry, T., DeBoer, D. J., Favrot, C., Jackson, H. A., Mueller, R. S., Nuttall, T., \& Prélaud, P. (2015). Treatment of canine atopic dermatitis: 2015 updated guidelines from the International Committee on Allergic Diseases of Animals (ICADA). BMC Veterinary Research, 11(1), 1-15.

Olivry, T., DeBoer, D. J., Griffin, C. E., Halliwell, R. E., Hill, P. B., Hillier, A., Marsella, R., \& Sousa, C. A. (2001). The ACVD task force on canine atopic dermatitis. Veterinary Immunology and Immunopathology, 81, 143-383.

Olivry, T., DeBoer, D. J., \& Prélaud, P. (2007). Food for thought: pondering the relationship between canine atopic 620 dermatitis and cutaneous adverse food reactions. Veterinary Dermatology, 18, 390-391.

Ribeiro, J. Z. M., Martins, B. O., Hotz, M. R., Almeida, V. G. F., Cunha, N. C., \& Dieckmann, A. M. (2020). Análise da ocorrência dos critérios de Favrot e das comorbidades apresentadas por cães com dermatite atópica atendidos no Hospital Veterinário da Universidade Federal Fluminense. Revista Brasileira de Ciência Veterinária, 27(3), 104-109.

Rybníček, J., Lau-Gillard, P. J., Harvey, R., \& Hill, P. B. (2009). Further validation of a pruritus severity scale for use in dogs. Veterinary Dermatology, 20(2), $115-122$.

Santoro, D. (2019). Therapies in Canine Atopic Dermatitis: An update. Veterinary Clinics of North America: Small Animal Practice, 49, 9-26.

Santos, J. P. M. F. (2017). Mastocitoma cutâneo canino: Inflamação cutânea crónica VS desenvolvimento de mastocitomas. Dissertação (Mestrado), Universidade Lusófona de Humanidades e Tecnologias, Lisboa.

Santos, M. G. O. \& Santos, M. M. (2016). Perfil da dermatite atópica canina em Salvador - Brasil. PUBVET, 10(11), 839-843.

Saridomichelakis, M. N. \& Olivry, T. (2016). An update on the treatment of canine atopic dermatitis. The Veterinary Journal, $207,29-37$.

Souza, T. M., Fighera, R. A., Sschmidt, C., Réquia, A. H., Brim, J. S., Martins, T. B., \& Barros, C. S. L. (2009). Prevalência das dermatopatias não-tumorais em cães do município de Santa Maria, Rio Grande do Sul (2005-2008). Pesquisa Veterinária Brasileira, 29(2), 157-162.

Wilhem, S., Kovalik, M., \& Favrot, C. (2011). Breed-associated phenotypes in canine atopic dermatitis. Veterinary Dermatology, $22(2), 143-149$.

Wood, S. H., Clements, D. N., Ollier, W. E., Nuttall, T., McEwan, N. A., \& Carter, S. D. (2009). Gene expression in canine atopic dermatitis and correlation with clinical severity scores. Journal of Dermatological Science, 55, 27-33.

Zur, G., Ihrke, P. J., White, S. D., \& Kass, P. H. (2002). Canine atopic dermatitis: a retrospective study of 266 cases examined at the University of California, Davis, 1992-1998. Part I: Clinical features and allergy testing results. Veterinary Dermatology, 13, 89-102. 